UDC $517.11+519.92+539.3$

\title{
NONLINEAR OSCILLATIONS OF A PRESTRESSED CONCRETE BRIDGE BEAM SUBJECTED TO HARMONIC PERTURBATION IN THE CONDITIONS OF INDETERMINACY OF PARAMETERS
}

\author{
S.V. Baiev, \\ Doctor of technical science, professor \\ D.L. Volchok, \\ Phd, associate professor \\ Prydniprovska State Academy of Civil Engineering and Architecture \\ DOI: $10.32347 / 2410-2547.2020 .104 .147-163$
}

\begin{abstract}
This paper deals with the nonlinear oscillations of a prestressed reinforced concrete beam firmly attached to two supports. The beam is subjected to a harmonic force. The calculations of such beams are associated with a number of uncertainties in the initial data. This publication is devoted to questions of their correct accounting.

For a long period of time in mechanics, to tack into account some uncertainties, they have been using the probability theory for modeling and such theory dominates. It have been proven that the probability theory can solve a lot of problems but nevertheless it has some weaknesses. In particular, the lack of statistical information or incomplete information does not adequately reflect the real object of study in a mathematical model. Recently, many researchers have noted that the uncertainty in construction is not only stochastic in nature, and this provides an impetus for the introduction of new developing methods and theories of soft computing. Among them, theories of fuzzy and rough sets, the reliability of which has already been proven in solving control problems, etc. They are the most popular and effective theories now.

For the beam under consideration, the amplitude of beam oscillations is determined, provided that its parameters are indeterminate (fuzzy) and vary within certain limits. An example of determining the amplitude of the oscillation of the 33-meter-long prestressed beam designed by Soyuzdorproekt is studied. The membership function for the amplitude of the beam transverse oscillations using the theory of fuzzy numbers is constructed. The influence analysis of the fuzziness of the disturbance frequency value on the amplitude of oscillations is performed.

It has been revealed that even a small indeterminacy in the frequency setting can cause the beam damage, although there will not yet be any damage when setting the accurate frequency. Thus for the value $\omega_{3}^{(0)}=18.2$, the corresponding value $A_{3}^{(0)}$ of the right endpoint of the amplitude interval exceeds the maximum acceptable value of $0.076 \mathrm{~m}$, although the modal value of the amplitude does not exceed the acceptable value. Therefore, when calculating the amplitude of structural oscillations, the interval endpoints of the frequency variation should be taken into account, and not its modal value. Analysis of the table shows that further increase in the oscillations frequency leads to resonance, because it moves beyond the acceptable limits both the endpoints of the interval of undetermined amplitude, and the modal value.
\end{abstract}

Keywords: forced oscillations of prestressed concrete beam, membership function, perturbation frequency, the theory of fuzzy numbers.

\section{INTRODUCTION}

The project designing is connected with the parameters of materials needed for its creation such as the elasticity modulus of concrete and steel. They are not determined as well as the dimensions of units of the unbuilt construction Therefore, at the design stage one should take into account the indeterminacy of

(C) Baiev S.V., Volchok D.L. 
parameters and foresee its further consequences. We will show how to take into account the indeterminacy of the parameters for defining the amplitude of the oscillations of the prestressed concrete T-shaped cross section beam objected to harmonic perturbation. Prestressed concrete beams are widely applied in bridge construction due to the use of high-strength reinforcement. It is known that concrete is well-compressed but it does not work well in tension. Therefore, the reinforcing frame includes high-strength rebar. To fully use the carrying capacity, the high-strength rebar is stretched between stops before its concreting. Without pre-tension of the reinforcement the concrete layer inside it is not able to withstand stretching and may crack. This cannot be allowed, because the moisture that penetrates into the cracks from outside will cause corrosion of the reinforcement. In addition, cyclic freezing and thawing destroys the beam. Therefore, pre-tension of the reinforcement is applied. Such 33-meter-long beams have been designed by "Soyuzdorproekt" and applied in bridges for over 50 years. The precast beams are manufactured with the help of the rolling stands. First, the reinforcement frame including 10 bunches of $5 \mathrm{~mm}$ high-strength wire is mounted on a metal rolling stand. Each bunch consists of 24 wires. There are anchors at the ends of the bunch. The main task of an anchor is to pass on the tensile force of the bunch to the concrete after his release from the catch. After stretching the bunches to the designed size the stand with the frame and tensioned bunches is rolled into the casting workshop. After casting with concrete, the beam doesn't reach the designed strength. Thus the beam is rolled into the steaming chamber where it is kept for 24 hours at a temperature of $90^{\circ} \mathrm{C}$. It reaches the designed strength in this chamber (under normal conditions it takes 28 days). After steaming the

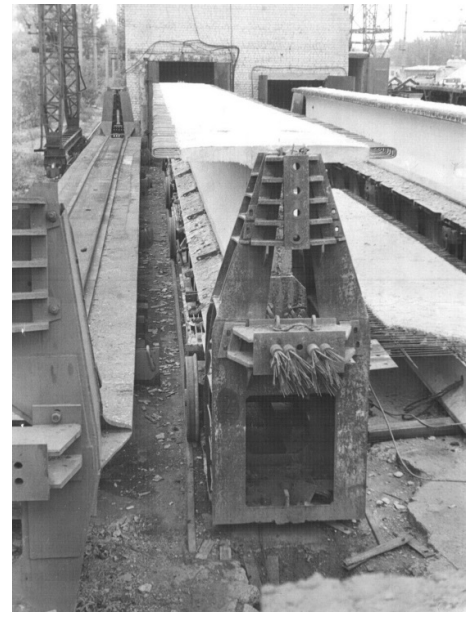

Fig. 1. A prestressed beam on a stand finished beam is rolled to the warehouse (Fig. 1). The bunches are released from the catches there. As concrete compresses the beam flexes upwards. Calculation of the tensile force of the bunches provides the absence of cracks in the top layer of the beam.

Consider the forced transverse vibrations $y(z, t)$ of the beam with the constant moment of inertia of section $I$, the modulus of elasticity of concrete $E$, the cross-sectional area $S$, the length $l$, and the linear mass $m$. Here $z$ is the abscissa of the point of the beam axis, $t$ is time. Let us consider the case where both supports on which the beam rests, for some reason are stationary (Fig. 2). In this case, a horizontal reaction $H$ arises under the transverse displacement, and it is determined by the following formula 


$$
H=\frac{E S}{l} \cdot \int_{0}^{l} y_{z}^{2} d z
$$

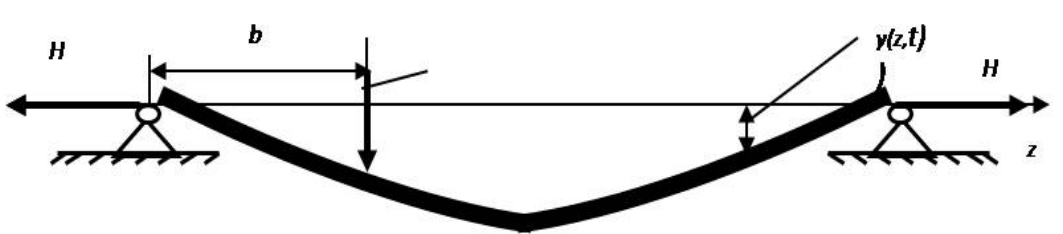

Fig. 2. Sketch of the beam fixed on two supports

The transverse variable force affects the beam $F_{0}(t)$. Taking into account the formula (1.1) and according to N.G. Bondar [1], we obtain the following equation of oscillations

$$
L(z, t)=\frac{E I}{m} \cdot\left(y_{z z z z}-a \cdot y_{z z} \cdot \int_{0}^{l} y_{z}^{2} d z\right)+y_{t t}-\frac{F_{0}(t) \cdot \delta(z-b)}{m}=0 .
$$

Here, the subscript for the function $y$ denotes the partial derivative with respect to the corresponding variable, $\delta(z)-\delta$ is the Dirac function, and $b$ is a point of application of a force. We seek a solution in the following form

$$
y(z, t)=x \cdot \sin \frac{\pi z}{l},
$$

where $x=x(t)$. This solution satisfies zero geometric and force conditions. In accordance with the Bubnov-Galerkin method, we substitute function (1.3) for equation (1.2) and minimize the functional

$$
\int_{0}^{l} L(z, t) \cdot \sin \frac{\pi z}{l} d z
$$

We result at the Duffing's equation

$$
\ddot{x}+a \cdot x+\beta \cdot x^{3}=F_{1}(t),
$$

Where

$$
a=\frac{\pi^{4} E I}{m l^{4}}, \quad \beta=a \cdot \frac{S}{4 I}, \quad F_{1}(t)=\frac{2 F_{0}(t)}{l \cdot m} \sin \frac{\pi b}{l} .
$$

Let $F_{0}(t)=f \cdot \sin \omega \cdot t$, where $f$ is the amplitude of the perturbing force, $t$ is time, $\omega$ is the frequency of harmonic perturbation. Let the perturbing force be applied in the middle of the beam $\left(\sin \frac{\pi b}{l}=1\right)$. After the replacement of $\frac{2 \cdot f}{l \cdot m}=F$, equation (1.4) is expressed as

$$
\ddot{x}+a \cdot x+\beta \cdot x^{3}=F \sin \omega t .
$$

Thus, the problem of oscillations of a beam with the geometric nonlinearity leads to the solution of the Duffing's equation with a strict characteristic of the 
restoring force $(a>0, \beta>0)$ The problem of oscillations of a beam with the physical nonlinearity also leads to the Duffing's equation (1.4), when the tension is connected with the relative elongation by the relationship

$$
\sigma=E \cdot \varepsilon+\beta_{0} \cdot \varepsilon^{3} \text {. }
$$

In this case, the coefficient $\beta$ can be either positive or negative.

In articles $[2,3]$ a fuzzy double crisis is observed in the forced Duffing's oscillator with multiplicative fuzzy noise. The Duffing's equation contains only one fuzzy parameter with triangular membership function. In this paper, we consider the forced Duffing's oscillator having several triangular fuzzy parameters. Let us consider the stationary mode of oscillations of a system, according to which the principal component of the solution has the form of the right-hand part. Naturally, this regime occurs under certain initial conditions.

\section{PROBLEM DEFINITION}

Let us construct an approximate solution by the Duffing's method. In order to reduce the quantity of equation parameters, we proceed to dimensionless variables. Let $x_{0}$ be the static deviation of the corresponding linear system

$$
x_{0}=\frac{F}{a} .
$$

A new dimensionless variable $y$ can be defined by the equality

$$
y=\frac{x}{x_{0}} .
$$

This is a relative displacement. Taking into account the equality (2.1), we obtain from the equality (2.2) the following

$$
y=\frac{x \cdot a}{F} .
$$

We proceed to the dimensionless argument $\tau$ connected with the variable $t$ by the equality

$$
\sqrt{a} \cdot t=\tau .
$$

Considering the equations (2.3) and (2.4), we result at the equation in dimensionless variables, which has already got one parameter $\gamma$ instead of three

$$
\frac{d^{2} y}{d \tau^{2}}+y+\gamma \cdot y^{3}=\sin v \cdot \tau \text {. }
$$

Here

$$
\begin{gathered}
\gamma=\frac{\beta \cdot F^{2}}{a^{3}}, \\
v=\frac{\omega}{\sqrt{a}} .
\end{gathered}
$$

Let the null approximation have the form of the right-hand part and is a harmonic 


$$
y=A \sin v \cdot \tau
$$

with not yet defined amplitude $A$. Depending on the initial conditions, the value of the amplitude $A$ can be either positive, which corresponds to the inphase oscillations with the active force, or negative, which corresponds to the oscillations in the antiphase, respectively. The null approximation satisfies the initial conditions

$$
\tau=\frac{\pi}{2 \cdot \omega}, y=A, \frac{d y}{d \tau}=0 .
$$

In accordance with Dufing's idea, we add to both parts of equality (1.6) the expression $v^{2} \cdot y$. We get the following

$$
\frac{d^{2} y}{d \tau^{2}}+v^{2} \cdot y+y+\gamma \cdot y^{3}=\sin v \cdot \tau+v^{2} \cdot y .
$$

Substituting the expression (2.8) for the variable $y$ for the right-hand part of the equation as well as the third and the fourth members from the left-hand part of it, we result at the equality

$$
\frac{d^{2} y}{d \tau^{2}}+v^{2} \cdot y=\sin v \cdot \tau \cdot\left(1-A+v^{2} A-\frac{3}{4} \cdot \gamma \cdot A^{3}\right)+\frac{1}{4} \cdot \gamma \cdot A^{3} \sin 3 \cdot v \cdot \tau .
$$

The eigenfrequency of the linear system, artificially created as a result of the adding the summand $v^{2} \cdot y$ to both parts of the equation, coincides with the frequency of the first right-hand part summand. To exclude resonance, the expression in parentheses from the right-hand part should be equated to zero. This is the sense of the Duffing's idea. We reach the equation for determining the amplitude

$$
1-A+v^{2} A-\frac{3}{4} \cdot \gamma \cdot A^{3}=0,
$$

The last equality is the amplitude-frequency characteristic equation. Now the equation (2.10) is expressed as

$$
\frac{d^{2} y}{d \tau^{2}}+v^{2} \cdot y=\frac{1}{4} \cdot \gamma \cdot A^{3} \sin 3 \cdot v \cdot \tau
$$

A particular solution of this equation which satisfies the initial conditions (2.9) is expressed by the equality

$$
y=A \sin v \cdot \tau+\frac{\gamma \cdot A^{3}}{32 \cdot v^{2}} \cdot(\sin v \cdot \tau-\sin 3 \cdot v \cdot \tau) .
$$

This equality describes the first approximation of the equation solution (2.5). The equation (2.11) of the amplitude-frequency characteristic (AFC) of the null approximation contains only one parameter $\gamma$. The diagram of the function $v$ under $\gamma=1$ is shown in Fig. 3.

By replacing the variables in this equation, you can get rid of this parameter as well. First, we find the minimum point of the diagram of the perturbation 
frequency $v$ and the oscillations amplitude $A$ relationship. This point has the following coordinates

$$
A^{*}=-\sqrt[3]{\frac{2}{3 \cdot \gamma}}, v^{*}=\sqrt{1+3 \cdot \sqrt[3]{\frac{3 \cdot \gamma}{16}}} .
$$

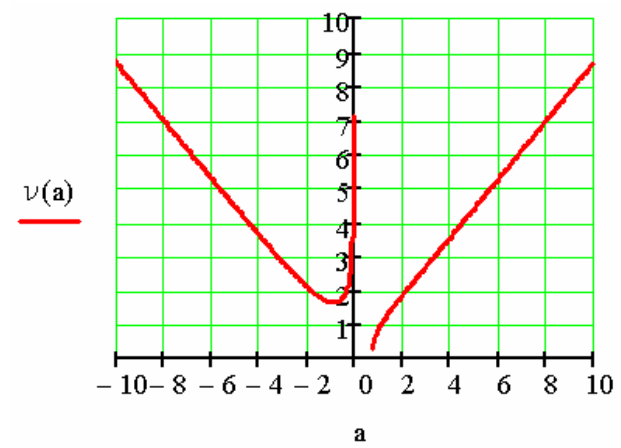

Fig.3. Diagram of the amplitude-frequency relationship

We enter new dimensionless variables $c$ and $d$ and express through them the amplitude $A$ and oscillations frequency $v$, by the formulas

$$
\begin{gathered}
A=-d \cdot \sqrt[3]{\frac{2}{3 \cdot \gamma}}, \\
v=\sqrt{1+3 \cdot c \cdot \sqrt[3]{\frac{3 \cdot \gamma}{16}}} .
\end{gathered}
$$

The substitution units in these equalities instead of variables $c$ and $d$ gives us the coordinates of the minimum point of the function $v$. Substituting the right-hand parts of equations (2.12) and (2.13) into equation (2.11), we result at the equation in new dimensionless variables $c$ and $d$ :

$$
d^{3}-3 \cdot c \cdot d+2=0
$$

which no longer contains any parameter. The diagram of the relationship between the variables $c$ and $d$ is shown in Fig. 4. From equality (2.13) we express the variable $c$ through the frequency $v$ :

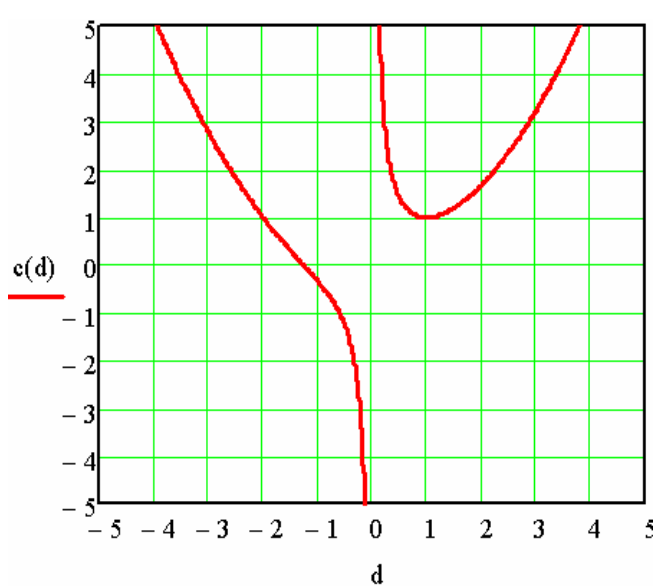

Fig. 4. Diagram of relationship between $c$ and $d$

$$
c=\frac{4 \cdot\left(v^{2}-1\right)}{3 \cdot \sqrt[3]{12 \cdot \gamma}} .
$$

Taking into account the equalities (2.6) and (2.7), we find

$$
c=\frac{4 \cdot\left(\omega^{2}-\alpha\right)}{3 \cdot \sqrt[3]{12 \cdot \beta \cdot F^{2}}} .
$$

The equality (2.3) shows that the amplitude $A_{0}$ of the oscillations of the variable $x$ is related to the amplitude $A$ of the dimensionless variable $y$ by the equality 


$$
A_{0}=\frac{A \cdot F}{a} .
$$

Taking into account the equalities (2.6) and (2.12), after simplification we obtain

$$
A_{0}=-d \cdot \sqrt[3]{\frac{2 \cdot F}{3 \cdot \beta}} .
$$

According to the Cardano formulas, from the equation (2.14) we find the value $d$ as a function $c$ :

$$
\begin{gathered}
d=d(c)=W(c)+V(c) \text { for any value of } c \\
d=d a(c)=-0.5 \cdot(W(c)+V(c))+0.5 \cdot(W(c)-V(c)) \cdot \sqrt{-3}, \text { if } c>1 \\
d=d b(c)=-0.5 \cdot(W(c)+V(c))-0.5 \cdot(W(c)-V(c)) \cdot \sqrt{-3}, \text { if } c>1
\end{gathered}
$$

Here the following is expressed

$$
W(c)=\sqrt[3]{-1+\sqrt{1-c^{3}}}, \quad V(c)=\sqrt[3]{-1-\sqrt{1-c^{3}}} .
$$

The diagram of the function $d$ is shown in Fig. 5. The equation (2.14) has a single real root if $c<1$, and it is defined by the formula (2.17). If $c>1$, the equation (2.14) has three real roots, and they are defined by formulas (2.17), (2.18) and (2.19). In this case, the branch of the diagram that corresponds to the formula (2.18) for $c>1$, and formula (2.17) for $c<1$, determines the negative values of the root $d$ and corresponds to the large (inphase) oscillations of the beam.

The branch of the diagram, which corresponds to the formula (2.17) for $c>1$,

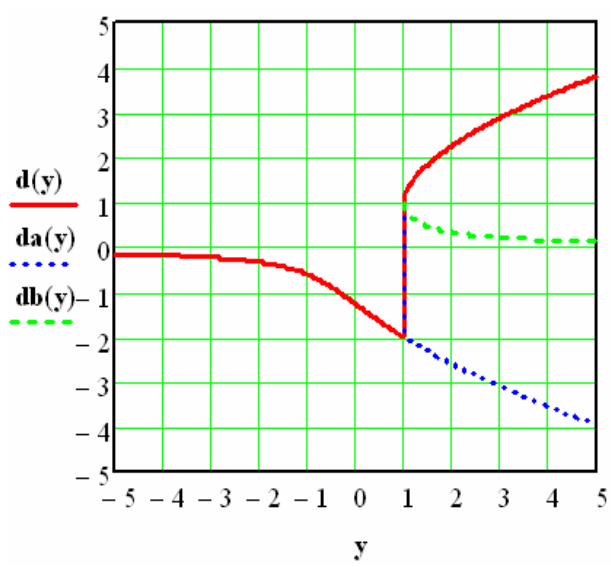

Fig. 5. Diagram of the function $d$ determines the large positive values of the root. It is proved that they correspond to unstable points of the amplitude-frequency characteristic, so they should not be taken into account. The branch which is defined by the formula (2.19) for $c>1$ determines the smaller positive values.

It corresponds to the small (antiphase) oscillations of the beam. The relationship between the function $d$ and parameter $c$ for large oscillations takes the following form

$$
d=d m(c)=\left\{\begin{aligned}
d a(c), \text { if } & c>1, \\
d(c), \text { if } & c \leq 1
\end{aligned}\right.
$$




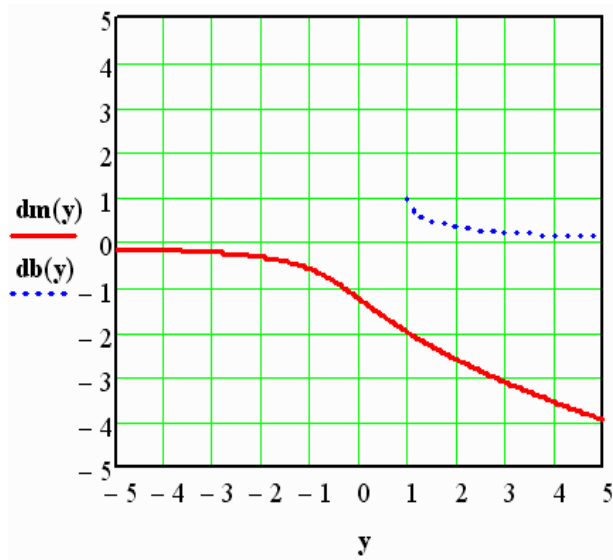

Fig.6. Diagram of the function $d$ for large and small oscillations

The diagram of the relationship between the function $d$ and parameter $c$ denoted by a continuous line for large (in-phase) oscillations, and by a dashed line for small (antiphase) oscillations is shown in Fig. 6.

The realization of large or small oscillations depends on the initial conditions. Taking into account equalities (2.15) and (2.16), we obtain the amplitude of oscillations $A_{0}$.

Let us calculate the amplitude of oscillations under undetermined values of parameters of the T-shaped prestressed beam. We will consider the beam parameters as undetermined triangular numbers, because they have valuable properties such as the simplicity of the description and the clarity of the interpretation, the keeping of the form when adding and subtracting, and the convenience of decomposition on a $\alpha$ - level system. Besides, there is no statistics for such a problem. A cross section of the beam is shown in Fig. 7. All sizes are given in millimeters. Here $h=1730 \mathrm{~mm}, a=200 \mathrm{~mm}, b=580 \mathrm{~mm}$, $e=1400 \mathrm{~mm}, c=20 \mathrm{~mm}$. We calculate the moment of inertia of the beam cross section. First, we determine the position of the neutral axis $y_{0}$ with respect to the lower face of the cross section. The standard stress $P_{a r}$ in one

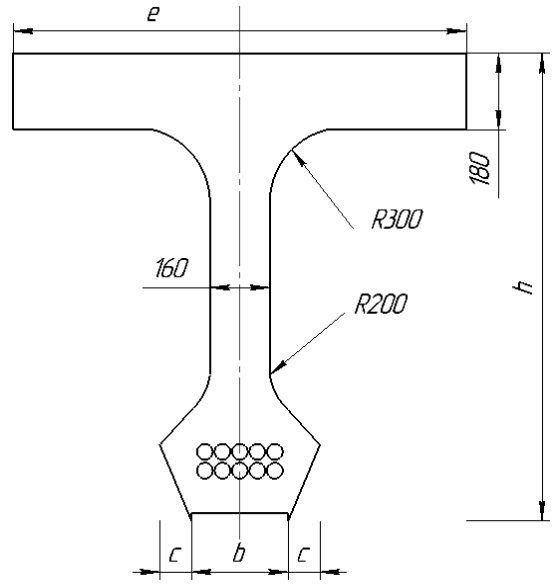

Fig. 7. Cross-section of the beam bunch is equal to $499300 \mathrm{~N}$ and corresponds to the stretching of the reinforcement by $198 \mathrm{~mm}$. After cutting the bunches, the concrete shrinks and the stress in the beam decreases. We determine the total stress in ten bunches after concrete compression. The tension stress of the reinforcement after compression of concrete decreases and is expressed as $P_{s n}=10 \cdot P_{a r} \cdot \frac{0.198-x}{0.198}$. Equating it to the compression stress of concrete which is equal to $S \cdot \frac{x}{l} \cdot E$ we find the value $x$ of the 
contraction of the bunches: $x=0.0086 \mathrm{~m}$. Here $S=0.704 \mathrm{~m}^{2}$ is the area of the beam cross section, $E=26 \cdot 10^{9} \mathrm{~Pa}$ is the modulus of elasticity of concrete of a B 35 rate, $l=33 \mathrm{~m}$ is the length of the beam.

The reduced tension force of the bunches $P_{s n}$ is $4.776 \cdot 10^{6} \mathrm{~N}$. The position of the neutral axis depends on the stress in the tensioned reinforcement. The manufactured beam lies on the rolling stand and is under the influence of its own weight and compressive force passed from the prestressed reinforcement. The beam lying on the stand, in accordance with the design, has a short-term bend $\Delta$ caused by the prestressing force and its own weight and it is equal to $32.5 \mathrm{~mm}$.

We result at the equation with respect to the value $y_{0}$ :

$$
\frac{M\left(y_{0}\right) \cdot l^{2}}{8 \cdot E \cdot I\left(y_{0}, \delta\right)}+\frac{5}{384} \cdot \frac{q \cdot l^{4}}{E \cdot I\left(y_{0}, \delta\right)}-\Delta=0 .
$$

Here the first summand is the inflection from the beam compression by stretched beams, the second summand is the deflection from the beam's own weight, $q$ is the load from the beam's own weight $q=17218 \mathrm{~N} / \mathrm{m}, M\left(y_{0}\right)$ is the moment of the compression of the concrete by prestressed reinforcement

$$
M\left(y_{0}\right)=P_{s n} \cdot\left(y_{a}-y_{0}\right) .
$$

Here $y_{a}$ is the distance from the lower face of the cross section to the center of the bunches. The moment of inertia is a function of the position of the neutral axis $y_{0}$ and the deviation $\delta$ of the cross-sectional dimensions from the designed values. It is defined by the following formula

$$
\begin{gathered}
I\left(y_{0}, \delta\right)=2\left[\int_{0}^{0.08+\delta} \int_{0}^{1.73+\delta}\left(y-y_{0}\right)^{2} d y d x+\right. \\
+\int_{0.08+\delta}^{0.138+\delta} \int_{0}^{1.73-\sqrt{0.04-(x-0.28-\delta)^{2}}}\left(y-y_{0}\right)^{2} d y d x+\int_{0.138+\delta}^{0.31+\delta} \int_{0}^{0.51-x}\left(y-y_{0}\right)^{2} d y d x- \\
-\int_{0.29+\delta}^{0.31+\delta} \int_{0}^{10 \cdot(x-0.29-\delta)}\left(y-y_{0}\right)^{2} d y d x+\int_{0.08+\delta}^{0.38+\delta} \int_{1.25+\sqrt{0.09-(x-0.38-\delta)^{2}}}^{1.73+x}\left(y-y_{0}\right)^{2} d y d x+ \\
\left.+\int_{0.38+\delta}^{0.7+\delta} \int_{1.55}^{1.73+\delta}\left(y-y_{0}\right)^{2} d y d x\right] .
\end{gathered}
$$

Similarly, we calculate the cross-sectional area as a function of deviations of the cross-sectional dimensions. Let the dimensions of the section have a deviation within the tolerance $\pm 0.003 \mathrm{~m}$. Solving the equation (2.20) and taking into account the equality (2.21), we can calculate the moment of inertia. Depending on the deviations of the cross-sectional dimensions, the cross-sectional area $S$ and the moment of inertia $I$ have the following values and intervals of variation

$$
\begin{gathered}
S=0.704 \mathrm{~m}^{2}, \quad 0.691 \mathrm{~m}^{2}<S<0.718 \mathrm{~m}^{2} ; \\
I=0.285 \mathrm{~m}^{4}, \quad 0.281 \mathrm{~m}^{4}<I<0.29 \mathrm{~m}^{4} .
\end{gathered}
$$

Let the undetermined length of the beam $l$, the linear mass $m$, the modulus of elasticity of the concrete $E$, the amplitude of the perturbation force $f$ and the 
perturbation frequency $\omega$, as well as their intervals of variation have the following values

$$
\begin{array}{cc}
l=33 \mathrm{~m}, & 32.99 \mathrm{~m}<l<33.01 \mathrm{~m} ; \\
m=1756 \mathrm{~kg} / \mathrm{m}, & 1724 \mathrm{~kg} / \mathrm{m}<m<1791 \mathrm{~kg} / \mathrm{m} ; \\
E=26 \cdot 10^{9} \mathrm{~Pa}, & 25 \cdot 10^{9} \mathrm{~Pa}<E<27 \cdot 10^{9} \mathrm{~Pa} ; \\
f=50 \mathrm{~N}, & 49.9 \mathrm{~N}<f<50.1 \mathrm{~N} ; \\
\omega=17.8 \mathrm{~Hz}, & 17.7 \mathrm{~Hz}<\omega<17.9 \mathrm{~Hz} .
\end{array}
$$

\section{DEFINITION OF AN UNDETERMINED TRIANGULAR NUMBER}

An undetermined triangular number is a number with a carrier $\operatorname{Supp}(A)=\left[a_{1}, a_{3}\right]$ with a single modal value for which $\mu A(x)=1$ and the membership function [4]:

$$
\mu A(x)=\left\{\begin{array}{cc}
\frac{x-a_{1}}{a_{2}-a_{1}}, & a_{1} \leq x \leq a_{2} ; \\
\frac{a_{3}-x}{a_{3}-a_{2}}, & a_{2} \leq x \leq a_{3} ; \\
0, & x<a_{1}, x>a_{3} .
\end{array}\right.
$$

The undetermined number function can be interpreted as a measure of the designer's confidence that all the points of a certain segment differ little from the determined value that belongs to it, and we probably do not know the determined value. It's natural that the longer the segment, the less confidence that all its points are close to the determined value. The membership function is a subjective evaluation. The values that the membership function takes are called the $\alpha$-level of the undetermined number. For example, if according to the results of all the studies the modulus of elasticity of concrete is expressed by the interval $\left[a_{1}, a_{3}\right]$, then its $\alpha$-level is equal to zero, and $\alpha$-level of the determined number is equal to one, because the determined number is the interval the ends of which are equal to it. The undetermined number is unimodal. If the condition $\mu_{A}(x)=1$ is true only for one value, this singular number is called a mode. It is obvious that the mode of the triangular number is $a_{2}$. Let all the parameters of the problem be unimodal undetermined numbers. We will operate with the undetermined parameters based on the interval method. The undetermined triangular number $A$ is completely defined by three determined numbers. Therefore it is expressed by $A=\left(a_{1}, a_{2}, a_{3}\right)$, and its $\alpha$-level interval is written as $A_{\alpha}=\left[a_{1}^{(\alpha)}, a_{3}^{(\alpha)}\right]$. It's obvious that $a_{1}=a_{1}^{(0)}, a_{3}=a_{3}{ }^{(0)}, a_{2}=a_{1}^{(1)}=a_{3}{ }^{(1)}$. Taking into account the expression (3.1), the ends of the interval $A_{\alpha}$ can be written as functions $\alpha$ :

$$
A_{\alpha}=\left[\left(a_{2}-a_{1}\right) \cdot \alpha+a_{1},-\left(a_{3}-a_{2}\right) \cdot \alpha+a_{3}\right] \text {. }
$$




\section{OPERATIONS ON UNDETERMINED NUMBERS BASED ON THE INTERVAL METHOD}

Let $A$ and $B$ be two undetermined, not necessarily triangular, but unimodal numbers with the $\alpha$-level intervals and $A_{\alpha}=\left[a_{1}^{(\alpha)}, a_{3}{ }^{(\alpha)}\right]$ and $B_{\alpha}=\left[b_{1}^{(\alpha)}, b_{3}^{(\alpha)}\right], \forall \alpha \in(0,1]$. The operations on the $\alpha$-level intervals of undetermined numbers $A$ and $B$ are performed according to the following rules

$$
\begin{aligned}
A_{\alpha}+B_{\alpha}=\left[a_{1}^{(\alpha)}, a_{3}{ }^{(\alpha)}\right]+\left[b_{1}^{(\alpha)}, b_{3}^{(\alpha)}\right]=\left[a_{1}^{(\alpha)}+b_{1}^{(\alpha)}, a_{3}^{(\alpha)}+b_{3}{ }^{(\alpha)}\right], \\
A_{\alpha}-B_{\alpha}=\left[a_{1}^{(\alpha)}, a_{3}^{(\alpha)}\right]-\left[b_{1}^{(\alpha)}, b_{3}^{(\alpha)}\right]=\left[a_{1}^{(\alpha)}-b_{1}^{(\alpha)}, a_{3}{ }^{(\alpha)}-b_{3}{ }^{(\alpha)}\right], \\
A_{\alpha} \cdot B_{\alpha}=\left[a_{1}^{(\alpha)}, a_{3}^{(\alpha)}\right] \cdot\left[b_{1}^{(\alpha)}, b_{3}^{(\alpha)}\right]= \\
=\left[\begin{array}{l}
\min \left\{a_{1}^{(\alpha)} \cdot b_{1}^{(\alpha)}, a_{1}^{(\alpha)} \cdot b_{3}^{(\alpha)}, a_{3}^{(\alpha)} \cdot b_{1}^{(\alpha)}, a_{3}{ }^{(\alpha)} \cdot b_{3}{ }^{(\alpha)}\right\} \\
\max \left\{a_{1}^{(\alpha)} \cdot b_{1}^{(\alpha)}, a_{1}^{(\alpha)} \cdot b_{3}{ }^{(\alpha)}, a_{3}{ }^{(\alpha)} \cdot b_{1}^{(\alpha)}, a_{3}^{(\alpha)} \cdot b_{3}^{(\alpha)}\right\}
\end{array}\right]
\end{aligned}
$$

The multiplication of the $\alpha$-level interval of the undetermined number by a determined number $k$ is defined by the following rule

$$
k \cdot A_{\alpha}=k \cdot\left[a_{1}^{(\alpha)}, a_{3}^{(\alpha)}\right]=\left[\min \left\{k \cdot a_{1}^{(\alpha)}, k \cdot b_{3}^{(\alpha)}\right\}, \max \left\{k \cdot a_{1}^{(\alpha)}, k \cdot b_{3}^{(\alpha)}\right\}\right] .
$$

The inverse $\alpha$-level interval of the undetermined number is the undetermined number

$$
\left(A_{\alpha}\right)^{-1}=\frac{1}{A_{\alpha}}=\left[a_{1}^{(\alpha)}, a_{3}^{(\alpha)}\right]^{-1}=\left[\min \left\{\frac{1}{a_{1}^{(\alpha)}}, \frac{1}{a_{3}^{(\alpha)}}\right\}, \max \left\{\frac{1}{a_{1}^{(\alpha)}}, \frac{1}{a_{3}^{(\alpha)}}\right\}\right] .
$$

There is no need in division operation, because it can be reduced to multiplication by the inverse number.

Let us define the membership function of the amplitude of oscillations. First, let us calculate the $\alpha$-level of undetermined parameters $I, S, E, l, m, F, \omega$ :

$$
\begin{gathered}
I_{\alpha}=\left[I_{1}^{(\alpha)}, I_{3}^{(\alpha)}\right], S_{\alpha}=\left[S_{1}^{(\alpha)}, S_{3}^{(\alpha)}\right], E_{\alpha}=\left[E_{1}^{(\alpha)}, E_{3}^{(\alpha)}\right], l_{\alpha}=\left[l_{1}^{(\alpha)}, l_{3}^{(\alpha)}\right], \\
m_{\alpha}=\left[m_{1}^{(\alpha)}, m_{3}^{(\alpha)}\right], f_{\alpha}=\left[f_{1}^{(\alpha)}, f_{3}^{(\alpha)}\right], \omega_{\alpha}=\left[\omega_{1}^{(\alpha)}, \omega_{3}^{(\alpha)}\right] .
\end{gathered}
$$

Here the endpoints of the intervals are defined by the formulas:

$$
\begin{gathered}
I_{1}^{(\alpha)}=\left(I_{2}-I_{1}\right) \cdot \alpha+I_{1}, I_{3}^{(\alpha)}=-\left(I_{3}-I_{2}\right) \cdot \alpha+I_{3} ; I_{1}=0.281, I_{2}=0.285, \\
\quad I_{3}=0.29, \\
S_{1}^{(\alpha)}=\left(S_{2}-S_{1}\right) \cdot \alpha+S_{1}, S_{3}^{(\alpha)}=-\left(S_{3}-S_{2}\right) \cdot \alpha+S_{3} ; S_{1}=0.691, S_{2}=0.704, \\
\quad S_{3}=0.718, \\
E_{1}^{(\alpha)}=\left(E_{2}-E_{1}\right) \cdot \alpha+E_{1}, E_{3}^{(\alpha)}=-\left(E_{3}-E_{2}\right) \cdot \alpha+E_{3} ; E_{1}=25 \cdot 10^{9}, E_{2}=26 \cdot 10^{9}, \\
\quad E_{3}=27 \cdot 10^{9}, \\
l_{1}^{(\alpha)}=\left(l_{2}-l_{1}\right) \cdot \alpha+l_{1}, l_{3}^{(\alpha)}=-\left(l_{3}-l_{2}\right) \cdot \alpha+l_{3} ; l_{1}=32.99, l_{2}=33, l_{3}=33.01,
\end{gathered}
$$




$$
\begin{gathered}
m_{1}^{(\alpha)}=\left(m_{2}-m_{1}\right) \cdot \alpha+m_{1}, m_{3}^{(\alpha)}=-\left(m_{3}-m_{2}\right) \cdot \alpha+m_{3} ; m_{1}=1724, m_{2}=1756, \\
m_{3}=1791, \\
f_{1}^{(\alpha)}=\left(f_{2}-f_{1}\right) \cdot \alpha+f_{1}, f_{3}^{(\alpha)}=-\left(f_{3}-f_{2}\right) \cdot \alpha+f_{3} ; f_{1}=49.9, f_{2}=50, f_{3}=50.1, \\
\omega_{1}^{(\alpha)}=\left(\omega_{2}-\omega_{1}\right) \cdot \alpha+\omega_{1}, \omega_{3}^{(\alpha)}=-\left(\omega_{3}-\omega_{2}\right) \cdot \alpha+\omega_{3} ; \omega_{1}=17.7, \omega_{2}=17.8, \\
\omega_{3}=17.9 .
\end{gathered}
$$

Here and below, the moment of inertia is expressed by $\mathrm{m}^{4}$, the crosssectional area is expressed by $\mathrm{m}^{2}$, the modulus of elasticity is expressed by $\mathrm{Pa}$, the length is expressed by $\mathrm{m}$, the linear mass of the beam is expressed by $\mathrm{kg} / \mathrm{m}$, the amplitude of the perturbing force is expressed by $\mathrm{N}$, and the frequency of the perturbation is expressed by $\mathrm{Hz}$.

We calculate the membership functions of the parameters (1.5) of the Duffing's equation. From the first and second equalities of the expression (3.1), according to the above mentioned rules of operations on undetermined numbers, we calculate the endpoints of the intervals

$$
\begin{gathered}
a_{\alpha}=\left[a_{1}^{(\alpha)}, a_{3}^{(\alpha)}\right] \text { and } \beta_{\alpha}=\left[\beta_{1}^{(\alpha)}, \beta_{3}^{(\alpha)}\right]: \\
a_{1}^{(\alpha)}=\frac{\pi^{4} \cdot E_{1}^{(\alpha)} \cdot I_{1}^{(\alpha)}}{m_{3}^{(\alpha)} \cdot\left(l_{3}^{(\alpha)}\right)^{4}}, a_{3}^{(\alpha)}=\frac{\pi^{4} \cdot E_{3}^{(\alpha)} \cdot I_{3}^{(\alpha)}}{m_{1}^{(\alpha)} \cdot\left(l_{1}^{(\alpha)}\right)^{4}}, \beta_{1}^{(\alpha)}=\frac{a_{1}^{(\alpha)} \cdot S_{1}^{(\alpha)}}{4 \cdot I_{3}^{(\alpha)}}, \\
\beta_{3}^{(\alpha)}=\frac{a_{3}^{(\alpha)} \cdot S_{3}^{(\alpha)}}{4 \cdot I_{1}^{(\alpha)}} .
\end{gathered}
$$

Let us calculate the $\alpha$-level of the undetermined number $c_{\alpha}$ guided by the equality (2.15) by transforming the latter to the following form

$$
c_{\alpha}=R_{\alpha} W_{\alpha},
$$

where the following is denoted

$$
\begin{gathered}
R_{\alpha}=k \cdot\left(\frac{\omega_{\alpha}^{2}}{a_{\alpha}}-1\right), W_{\alpha}=\frac{a_{\alpha}}{\sqrt[3]{\beta_{\alpha} \cdot F_{\alpha}^{2}}} \cdot k=\sqrt[3]{\frac{16}{81}}, \\
R_{\alpha}=\left[R_{1}^{(\alpha)}, R_{3}^{(\alpha)}\right], W_{\alpha}=\left[W_{1}^{(\alpha)}, W_{3}^{(\alpha)}\right] .
\end{gathered}
$$

The endpoints of intervals are defined by the formulas:

$$
\begin{gathered}
R_{1}^{(\alpha)}=k \cdot\left(\frac{\left(\omega_{1}^{(\alpha)}\right)^{2}}{a_{3}^{(\alpha)}}-1\right), R_{3}^{(\alpha)}=k \cdot\left(\frac{\left(\omega_{3}^{(\alpha)}\right)^{2}}{a_{1}^{(\alpha)}}-1\right), \\
W_{1}^{(\alpha)}=\frac{a_{1}^{(\alpha)}}{\sqrt[3]{\beta_{3}^{(\alpha)} \cdot\left(F_{3}^{(\alpha)}\right)^{2}}}, W_{3}^{(\alpha)}=\frac{a_{3}^{(\alpha)}}{\sqrt[3]{\beta_{1}^{(\alpha)} \cdot\left(F_{1}^{(\alpha)}\right)^{2}}} .
\end{gathered}
$$

According to the rule of the triangular numbers multiplication, we get the $\alpha$ level interval of the parameter $c$ :

$$
c_{\alpha}=R_{\alpha} \cdot W_{\alpha}=\left[c_{1}^{(\alpha)}, c_{3}^{(\alpha)}\right],
$$


where the endpoints of the interval are defined by the formulas:

$$
\begin{aligned}
& c_{1}^{(\alpha)}=\min \left\{R_{1}^{(\alpha)} \cdot W_{1}^{(\alpha)}, R_{1}^{(\alpha)} \cdot W_{3}^{(\alpha)}, R_{3}^{(\alpha)} \cdot W_{1}^{(\alpha)}, R_{3}^{(\alpha)} \cdot W_{3}^{(\alpha)}\right\}, \\
& c_{3}^{(\alpha)}=\max \left\{R_{1}^{(\alpha)} \cdot W_{1}^{(\alpha)}, R_{1}^{(\alpha)} \cdot W_{3}^{(\alpha)}, R_{3}^{(\alpha)} \cdot W_{1}^{(\alpha)}, R_{3}^{(\alpha)} \cdot W_{3}^{(\alpha)}\right\} .
\end{aligned}
$$

After the calculation we have a non-triangular unimodal number

$$
c_{1}^{(0)}=-434.23, c_{1}^{(1)}=-201.437, c_{3}^{(0)}=-8.758 .
$$

Let the initial conditions be such that the beam carries out large oscillations.

\section{CALCULATION OF UNDETERMINED AMPLITUDE OF OSCILLATIONS}

The diagram of the function $d$ (Fig. 6) decreases monotonely which simplifies the calculation of the undetermined $\alpha$-level number intervals $d_{\alpha}=\left[d_{1}^{(\alpha)}, d_{3}^{(\alpha)}\right]$. The endpoints of the interval are defined by the equalities:

$$
d_{1}^{(\alpha)}=d\left(c_{3}^{(\alpha)}\right), \quad d_{3}^{(\alpha)}=d\left(c_{1}^{(\alpha)}\right) .
$$

Taking into account the equality (22), we calculate the endpoints of the $\alpha$ level intervals of the undetermined amplitude $A_{0 \alpha}=\left[A_{1}^{(\alpha)}, A_{3}^{(\alpha)}\right]$ :

$$
A_{1}^{(\alpha)}=-\sqrt[3]{\frac{2}{3}} \cdot d\left(c_{1}^{(\alpha)}\right) \cdot \frac{\left(F_{1}^{(\alpha)}\right)^{1 / 3}}{\left(\beta_{3}^{(\alpha)}\right)^{1 / 3}}, A_{3}^{(\alpha)}=-\sqrt[3]{\frac{2}{3}} \cdot d\left(c_{3}^{(\alpha)}\right) \cdot \frac{\left(F_{3}^{(\alpha)}\right)^{1 / 3}}{\left(\beta_{1}^{(\alpha)}\right)^{1 / 3}} .
$$

The membership function for the oscillation amplitude is convex but not triangular. The diagram of the undetermined amplitude membership function is shown in Fig. 8 which is calculated by the given undetermined parameters of the problem. The carrier of the undetermined amplitude of the nonlinear oscillations of the beam is the following interval

$$
\left[A_{1}^{(0)}, A_{3}^{(0)}\right]=\left[2.559 \cdot 10^{-5} \mathrm{~m} ; 1.401 \cdot 10^{-3} \mathrm{~m}\right] \text {. }
$$

The mode of undetermined amplitude $A_{2}$ is $5.797 \cdot 10^{-5} \mathrm{~m}$. The average value of the undetermined amplitude is calculated by the formula

$$
A_{s r}=\int_{0}^{1} \frac{A_{1}(\alpha)+A_{3}(\alpha)}{2} d \alpha
$$

and is equal to $5.797 \cdot 10^{-5} \mathrm{~m}$. In some cases, the middle of the interval for the $\alpha=0.5$ level membership function can be taken as the expected value of the undetermined number. We have

$$
A_{s r}=\frac{A_{1}(0.5)+A_{3}(0.5)}{2}=7.744 \cdot 10^{-5} \mathrm{~m} .
$$

Let us determine the largest amplitude of oscillations at which the yield of high-strength wire begins. We find the largest amplitude of oscillations provided that the deflection of the beam from the moment of the compression force of concrete by high-strength reinforcement, stretched up to the yield strength, is equal to the sum of the largest value of the oscillations amplitude and the deflection of the beam from its own weight. The largest compression-caused deflection of the beam $y_{\text {tek }}$ in the middle of the span is determined by the equality 


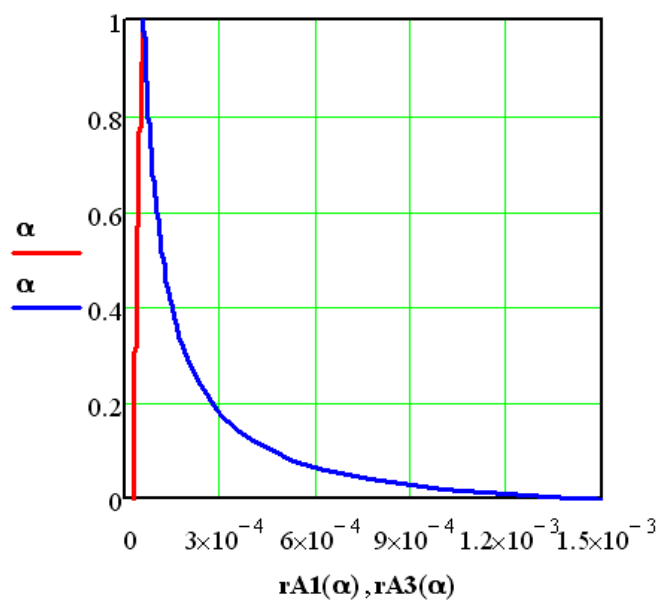

Fig. 8. Diagram of the undetermined amplitude of the oscillation function

$$
y_{\text {tek }}=\frac{P_{\text {tek }} \cdot\left(y_{0}-y_{a}\right) \cdot l^{2}}{8 \cdot E \cdot I} .
$$

Here $P_{\text {tek }}$ is the total stress from the stretched bunches at which the highstrength reinforcement yield begins.

According to the laboratory tests, the yield strength force for a single $5 \mathrm{~mm}$ wire is $32,340 \mathrm{~N}$, so we have $P_{\text {tek }}=7.762 \cdot 10^{6} \mathrm{~N}$. Taking into account the equality $y_{0}-y_{a}=0.792 \mathrm{~m}, \quad$ we obtain the largest deflection of the beam which is equal to $y_{\text {tek }}=0.111 \mathrm{~m}$. The deflection from the own weight of the beam in the middle of the span is $0.035 \mathrm{~m}$. Therefore the acceptable value of the oscillations amplitude is $0.076 \mathrm{~m}$. Table 1 shows the values of the endpoints of the intervals of the large oscillations amplitude $A_{1}^{(0)}$, $A_{3}^{(0)}$, and the modal value $A_{1}^{(1)}$, expressed in meters, as well as the values of the endpoints of the oscillation frequency intervals $\omega_{1}^{(0)}, \omega_{3}^{(0)}$, and the modal value $\omega_{1}^{(1)}$ expressed in hertz, respectively.

Table 1

Values of the endpoints of the intervals of the large oscillations amplitude $A_{1}^{(0)}, A_{3}^{(0)}$, and the modal value $A_{1}^{(1)}$

\begin{tabular}{|c|c|c|c|c|c|}
\hline$\omega_{1}^{(0)}$ & $\omega_{1}^{(1)}$ & $\omega_{3}^{(0)}$ & $A_{1}^{(0)}$ & $A_{1}^{(1)}$ & $A_{3}^{(0)}$ \\
\hline 9.9 & 10 & 10.1 & $5.594 \cdot 10^{-6}$ & $6.998 \cdot 10^{-6}$ & $8.778 \cdot 10^{-6}$ \\
\hline 17.7 & 17.8 & 17.9 & $2.559 \cdot 10^{-5}$ & $5.797 \cdot 10^{-5}$ & $1.401 \cdot 10^{-3}$ \\
\hline 17.75 & 18 & 18.2 & $2.637 \cdot 10^{-5}$ & $7.633 \cdot 10^{-5}$ & 0.284 \\
\hline 18.1 & 18.15 & 18.2 & $3.358 \cdot 10^{-5}$ & $1.0 \cdot 10^{-4}$ & 0.284 \\
\hline 19 & 19.1 & 19.2 & $1.232 \cdot 10^{-4}$ & 0.337 & 0.631 \\
\hline 19 & 19.5 & 20 & $1.232 \cdot 10^{-4}$ & 0.458 & 0.816 \\
\hline 26.84 & 26.85 & 26.86 & 1.259 & 1.527 & 1.844 \\
\hline
\end{tabular}

\section{CONCLUSIONS}

Analysis of the results given in the table shows that even a small indeterminacy in the frequency setting can cause the beam damage, although there will not yet be any damage when setting the accurate frequency. Thus for the 
value $\omega_{3}^{(0)}=18.2$, the corresponding value $A_{3}^{(0)}$ of the right endpoint of the amplitude interval exceeds the maximum acceptable value of $0.076 \mathrm{~m}$, although the modal value of the amplitude does not exceed the acceptable value. Therefore, when calculating the amplitude of structural oscillations, the interval endpoints of the frequency variation should be taken into account, and not its modal value. Analysis of the table shows that further increase in the oscillations frequency leads to resonance, because it moves beyond the acceptable limits both the endpoints of the interval of undetermined amplitude, and the modal value.

\section{REFERENCES}

1. M.G. Bondar. Nelinejnye statsionarnye kolebaniya (Nonlinear stationary oscillations). Science idea, Kiev, 1974. (in Russian)

2. L. Hong, J. Q. Sun. Double crises in fuzzy chaotic systems, Int. J.Dynam. Control, SpringerVerlag, Berlin, 32-40, 2013, DOI: 10.1007/s40435-013-0004-2

3. L. Hong, J. Jiang, J. Q. Sun. Crises in Chaotic Pendulum with Fuzzy Uncertainty, Journal of Applied Nonlinear Dynamics, 4(3), 215-221, 2015, DOI: 10.5890/JAND.2015.09.001

4. B. Liu. Theory and Practice of Uncertain Programming, Springer-Verlag, Berlin, 2009.

Стаття надійшла 21.02.2020

Баєв С.В., Волчок Д.Л.

\section{НЕЛІНІЙНІ КОЛИВАННЯ ПОПЕРЕДНЬО НАПРУЖЕНОЇ ЗАЛІЗОБЕТОННОЇ МОСТОВОЇ БАЛКИ ПРИ ГАРМОНІЙНОМУ ОБУРЕНІ В УМОВАХ НЕЧІТКИХ ПАРАМЕТРIВ}

Анотація. У даній роботі розглядаються нелінійні коливання попередньо напруженої залізобетонної балки, нерухомо закріпленої на двох опорах. Балка знаходиться під дією гармонійної сили. Розрахунки таких балок пов'язані з цілою низкою невизначеностей у вихідних даних. Питанням коректного їх врахування присвячується дана публікація.

Довгий час в механіці, для врахування невизначеностей, домінує використання теорії ймовірностей в моделюванні. Ця теорія довела свою ефективність у розв'язанні багатьох задач, але має і деякі слабкі сторони. Зокрема, недостатня статистична інформація або неповна інформація не дозволяє адекватно відображати реальний об'єкт дослідження в математичній моделі. Останнім часом багато дослідників відзначають, що невизначеність в будівництві носити не тільки стохастичний характер. Це дає поштовх для впровадження нових методів і теорій м'яких обчислень. Серед них найбільшу популярність і ефективність в даний час мають теорії нечітких і неточних множин, достовірність яких уже доведена при вирішенні задач управління і т.д.

Для розглянутої балки визначена амплітуда іï коливань за умови, що іï параметри $\epsilon$ нечіткими і змінюються в певних межах. Розглянуто приклад визначення амплітуди коливань попередньо напруженої балки довжиною 33 м, запроектованої Союздорпроект. Побудована функція належності амплітуди поперечних коливань балки з використанням теорії нечітких множин. Виконано аналіз впливу нечіткості завдання частоти обурення на амплітуду коливань. Виявлено, що навіть мала нечіткість в завданні частоти може викликати руйнування балки, хоч при чіткому завданні частоти руйнування ще не буде. Так для значення $\omega_{3}^{(0)}=18.2$ відповідне значення $A_{3}^{(0)}$ правого кінця інтервалу амплітуди перевищує граничне допустиме значення 0.076 м, хоча модальне значення амплітуди не перевищує допустиме значення. Отже, при обчисленні амплітуди коливань конструкцій в розрахунок слід брати кінці інтервалу зміни частоти, а не ії модальне значення. Аналіз показує, що подальше збільшення частоти коливань веде до резонансу, тому що виводить за допустимі межі і кінці інтервалу нечіткої амплітуди, і модальне значення.

Ключові слова: попередньо напружена залізобетонна балка, теорія нечітких множин, функція приналежності, частота збурень, амплітуда коливань. 
Баев С.В., Волчок Д.Л.

НЕЛИНЕЙНЫЕ КОЛЕБАНИЯ ПРЕДВАРИТЕЛЬНО НАПРЯЖЕННОЙ

ЖЕЛЕЗОБЕТОННОЙ МОСТОВОЙ БАЛКИ ПРИ ГАРМОНИЧЕСКОМ ВОЗМУЩЕНИИ В УСЛОВИЯХ НЕЧЕТКОСТИ ПАРАМЕТРОВ

Аннотация. В данной работе рассматриваются нелинейные колебания предварительно напряженной железобетонной балки, неподвижно закрепленной на двух опорах. Балка находится под действием гармонической силы. Расчёты таких балок сопряжены с целым рядом неопределённостей в исходных данных. Вопросам корректного их учёта посвящается данная публикация.

Долгое время в механике, для учёта неопределённостей, доминирует использование в моделировании теории вероятности. Она доказала свою эффективность в решении многих задач, но имеет и некоторые слабые стороны. В частности, недостаток статистической информации или неполная информация не позволяет адекватно отображать реальный объект исследования в математической модели. В последнее время многие исследователи отмечают, что неопределённость в строительстве носить не только стохастический характер, и это даёт толчок для внедрения новых развивающихся методов и теорий мягких вычислений. Среди них наибольшую популярность и эффективность в настоящее время имеют теории нечётких и неточных множеств, достоверность которых уже доказана при решении задач управления и т.д.

Для рассмотренной балки определена амплитуда ее колебаний при условии, что её параметры являются нечеткими и изменяются в известных пределах. Рассмотрен пример определения амплитуды колебаний преднапряжённой балки длиной 33 м, запроектированной Союздорпроектом. Построена функция принадлежности амплитуды поперечных колебаний балки с использованием теории нечётких множеств. Выполнен анализ влияния нечёткости задания частоты возмущения на амплитуду колебаний. Выявлено, что даже малая нечеткость в задании частоты может вызвать разрушение балки, хоть при четком задании частоты разрушения ещё не будет. Так для значения $\omega_{3}^{(0)}=18.2$ соответствующее значение $A_{3}^{(0)}$ правого конца интервала амплитуды превышает предельное допустимое значение 0.076 м, хотя модальное значение амплитуды не превосходит допустимое значение. Следовательно, при вычислении амплитуды колебаний конструкций в расчет следует брать концы интервала изменения частоты, а не ее модальное значение. Анализ показывает, что дальнейшее увеличение частоты колебаний ведет к резонансу, потому что выводит за допустимые пределы и концы интервала нечеткой амплитуды, и модальное значение.

Ключевые слова: предварительно напряженная железобетонная балка, теория нечётких множеств, функция принадлежности, частота возмущений, амплитуда колебаний.

\section{УДК $517.11+519.92+539.3$}

Баєв С.В., Волчок Д.Л. Нелінійні коливання попередньо напруженої залізобетонної мостової балки при гармонійному обурених в умовах нечітких параметрів // Опір матеріалів і теорія споруд: наук.-тех. збірник - К.: КНУБА, 2020. - Вип. 104. - С. 147-163. - Англ.

Для розглянутої балки визначена амплітуда ї̈ коливань за умови, щзо ї̈ параметри $\epsilon$ нечіткими і змінюються в певних межах.

Baiev S.V., Volchok D.L. Nonlinear oscillations of a prestressed concrete bridge beam subjected to harmonic perturbation in the conditions of indeterminacy of parameters // Strength of Materials and Theory of Structures: Scientific-and-technical collected articles. - K.: KNUBA, 2020. - Issue 104. - P. 147-163.

For the beam under consideration, the amplitude of its vibrations is determined, provided that its parameters are fuzzy and vary within known limits.

Баев С.В., Волчок Д.Л. Нелинейные колебания предварительно напряженной железобетонной мостовой балки при гармоническом возмущении в условиях нечеткости параметров // Сопротивление материалов и теория сооружений: науч.-тех. сборн. - К.: КНУБА, 2020. - Вып. 104. - С. 147-163. - Англ.

Для рассмотренной балки определена амплитуда ее колебаний при условии, что её параметры являются нечеткими и изменяются в известных пределах. 
Автор (вчена ступень, вчене звання, посада):

доктор технічних наук, професор, кафедра вищої математики БАСВ Станіслав Віталійович Адреса робоча: 49600, м. Дніпро, вул. Чернишевського, 24a. ДВНЗ "Придніпровська державна академія будівництва та архітектури,

Мобільний тел.: +38(066) 775-415-1

E-mail - Stanisl.Baev@gmail.com;

ORCID ID: http://orcid.org/0000-0002-9132-8487

Автор (вчена ступень, вчене звання, посада):

кандидат технічних наук, доцент, кафедра будівельної механіки та опору матеріалів ВОЛЧОК Денис Леонідович

Адреса робоча: 49600, м. Дніпро, вул. Чернишевського, 24a ДВНЗ "Придніпровська державна академія будівництва та архітектури.

Мобільний тел.: +38(066) 727-656-0

E-mail: Denys.L.Volchok@pgasa.dp.ua;

ORCID ID: http://orcid.org/0000-0002-7914-321X 